\title{
ISOLATION OF DANE PARTICLES CONTAINING A DNA STRAND BY METRIZAMIDE DENSITY GRADIENT
}

\author{
T. Takahashi, K. Kaga, Y. Akahane, T. Yamashita, Y. Miyakawa \\ AND M. MAYUMI \\ Kitasato Institute, Minato-ku, The Tokyo Metropolitan Institute of Medical Science, \\ Bunkyo-ku, National Institutes of Health, Shinagawa-ku, and Tokyo University Hospital, \\ Hongo, Tokyo, Japan
}

\section{Plate XII}

Dane, CAMERON and Briggs (1970) identified 42-nm "Dane" particles in the serum of individuals infected with hepatitis B virus (HBV), and they have been accepted as representing HBV. Dane particles share hepatitis $B$ surface antigen $\left(\mathrm{HB}_{\mathrm{s}} \mathrm{Ag}\right)$ with 20 -nm spherical and tubular forms, but their cores, hepatitis B core antigen $\left(\mathrm{HB}_{\mathrm{c}} \mathrm{Ag}\right.$ ), have a distinct antigenicity (Almeida, Rubenstein and Stott, 1971). We have developed a method for the isolation of Dane particles from the plasma of asymptomatic carriers of $\mathrm{HB}_{\mathrm{s}} \mathrm{Ag}$ on a large scale, and demonstrated a double-stranded DNA molecule extruding directly from their cores (Takahashi, T. et al., 1976). In the course of this study, we realised that the cores of Dane particles shedding a DNA strand were surprisingly few; more than $90 \%$ of Dane particles were thought to be "empty" because they did not seem to contain any DNA strand. The separation of the Dane particles containing DNA from such defective ones, to create a homogenous population of complete $\mathrm{HBV}$, would be a prerequisite for the study and understanding of their physicochemical properties, such as the DNA structure.

Birnie, Rickwood and Hell (1973) observed that the density of DNA decreased remarkably in the presence of metrizamide due to its hydration. They noted that DNA had a density of $1 \cdot 1$ $\mathrm{g} / \mathrm{cm}^{3}$ in metrizamide solution, as against $1.7 \mathrm{~g} / \mathrm{cm}^{3}$ in $\mathrm{CsCl}$ solution. Taking advantage of this phenomenon, we tried to separate the cores of Dane particles containing DNA from those without DNA.

\section{MATERIALS AND METHODS}

Isolation of Dane particles. Blood-plasma units of asymptomatic carriers containing hepatitis B e antigen ( $\left.\mathrm{HB}_{\mathrm{e}} \mathrm{Ag}\right)$ (Magnius and Espmark, 1972) were pooled, and Dane particles were isolated by a succession of steps including continuous flow zonal centrifugation, floating-type centrifugation, and rate zonal centrifugation (Takahashi, T. et al., 1976). When the purified preparation was observed in an electron microscope, more than $98 \%$ of all the particulate elements were identified as Dane particles. From 1.3 litres of plasma the yield of Dane particles was approximately $2 \times 10^{12}$.

Ultracentrifugation in metrizamide density gradient. The Dane-particle preparation was labelled with tritiated thymidine triphosphate $\left(\left[{ }^{3} \mathrm{H}\right] \mathrm{TTP}\right)$ in the presence of Nonidet P-40 (NP-40) by a modification (Moritsugu et al., 1975) of the method originally described by Kaplan et al. (1973), and a mixture of Dane-particle cores with and without radioactivity was obtained. Dane-particle core preparation $(1 \mathrm{ml})$ was brought to a density of $1.35 \mathrm{~g} / \mathrm{cm}^{3}$ by the addition of metrizamide (Nyegaard \& Co., AS, Oslo), and applied to the bottom of a Beckman SW-65 tube. A linear gradient of metrizamide, density $1.30-1.10 \mathrm{~g} / \mathrm{cm}^{3}$ (volume $4.5 \mathrm{ml}$ ) was prepared on the surface of the sample, and the tube was centrifuged at 50000 r.p.m. for $16 \mathrm{~h}$. Metrizamide solution with a density of $1.40 \mathrm{~g} / \mathrm{cm}^{3}$ was applied at the bottom, and $0.2-\mathrm{ml}$ 
fractions were collected from the surface. They were assayed for radioactivity in a scintillation counter and for $\mathrm{HB}_{\mathrm{c}} \mathrm{Ag}$ by the immune adherence haemagglutination (IAHA) method (Tsuda et al., 1975).

Electron microscopic observations. $\mathrm{HB}_{\mathrm{c}} \mathrm{Ag}$ preparations were spread in a monolayer after the method of Kleinschmidt (1968), and observed in a JEOL-JEM 100B electron microscope operating at $80 \mathrm{kV}$.

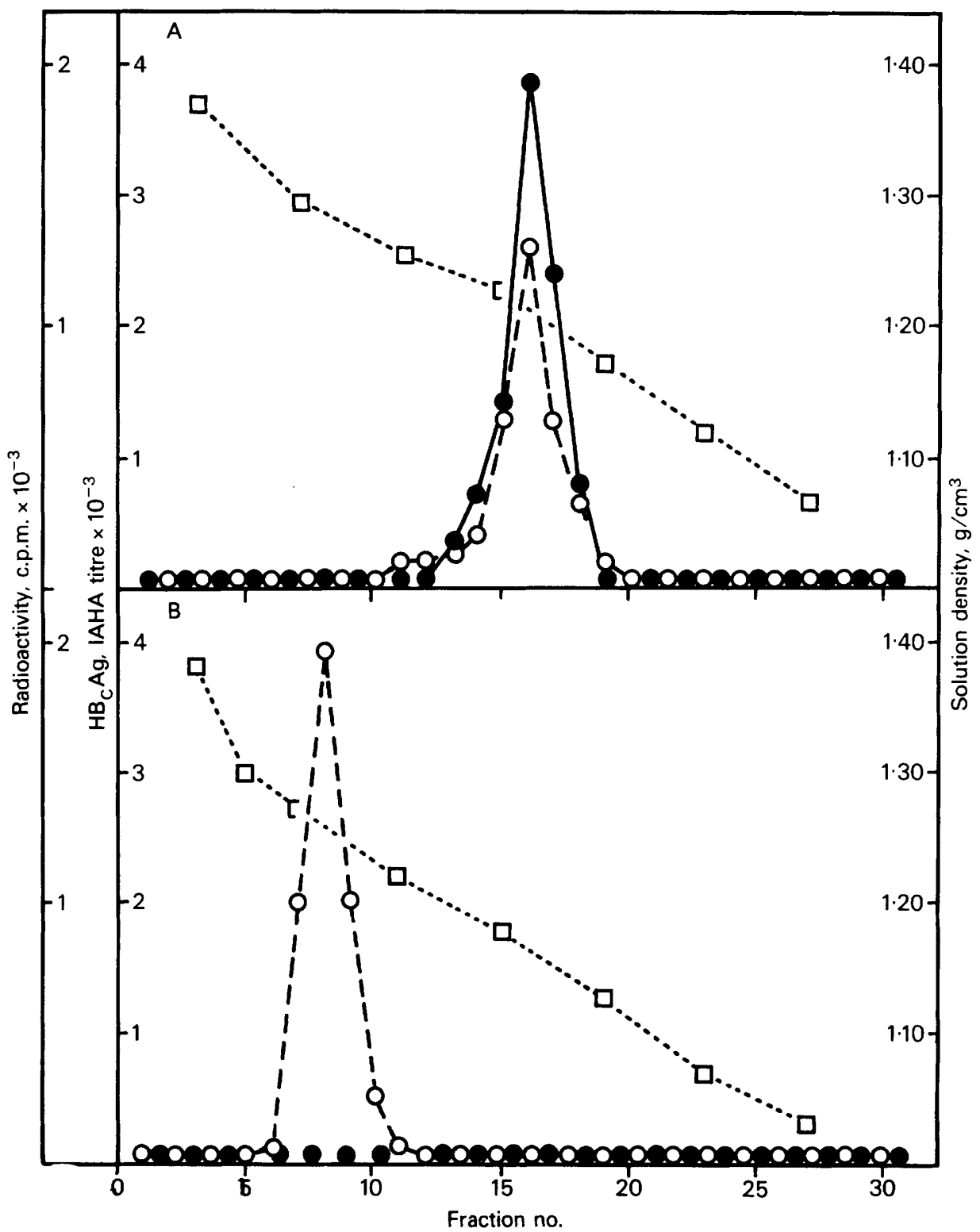

FIG. 1.-Ultracentrifugation of the cores of Dane particles in metrizamide density gradients.

A. The pattern of the core particles obtained at the lower density $\left(1 \cdot 19-1 \cdot 23 \mathrm{~g} / \mathrm{cm}^{3}\right)$. B. The pattern of the core particles obtained at the higher density $\left(1 \cdot 23-1 \cdot 27 \mathrm{~g} / \mathrm{cm}^{3}\right) . \bullet-\square$ Radioactivity as a measure of DNA polymerase activity; $0--0=$ hepatitis $B$ core antigen $\left(\mathbf{H B}_{\mathrm{c}} \mathbf{A}_{\mathrm{g}}\right)$; $0-------\mathrm{a}_{-}$density. 
ISOLATION OF HEPATITIS B VIRUS

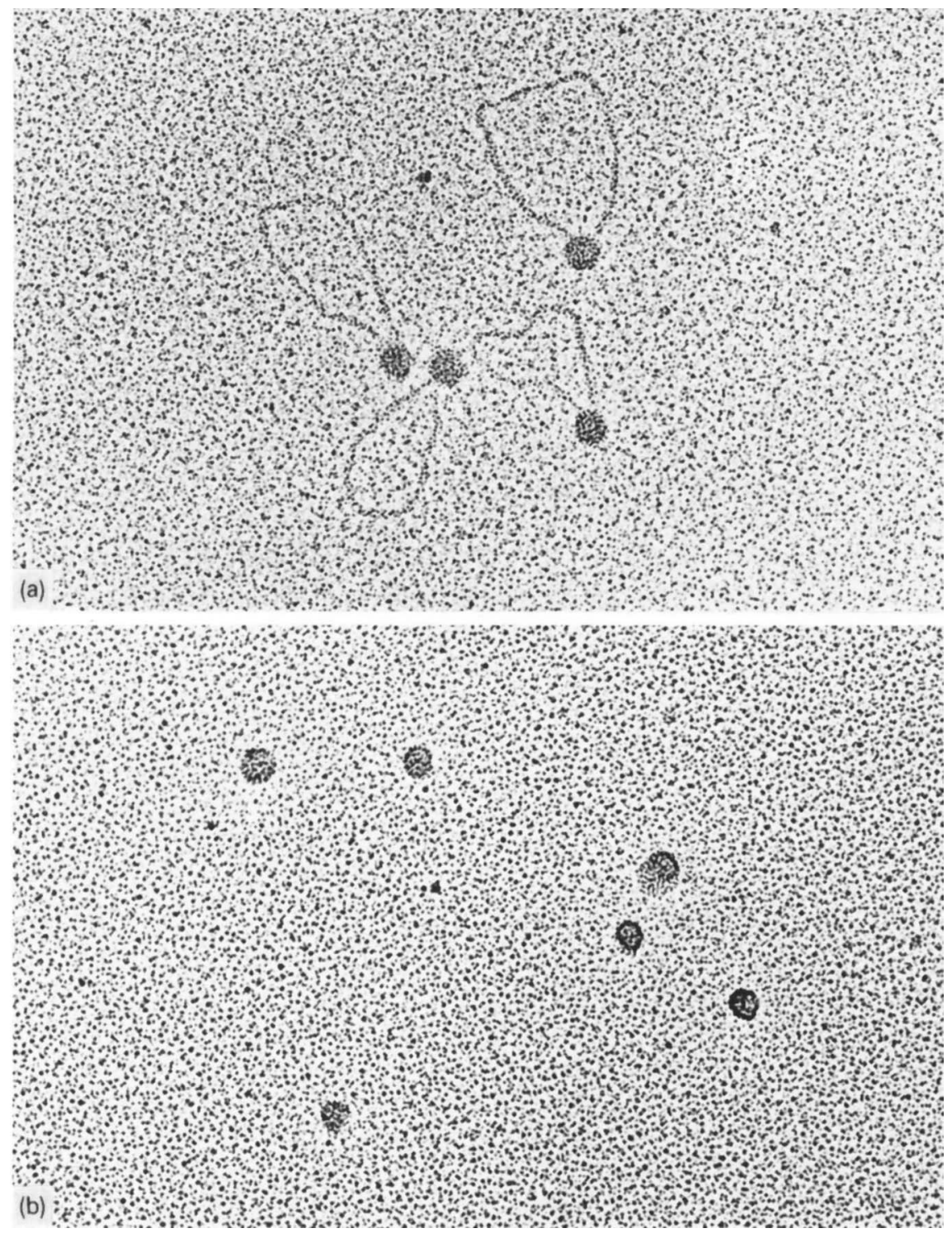

FIG. 2. (a). Electron micrograph (EM) of the cores of Dane particles obtained at the lower density of metrizamide; all cores expel a circular double-stranded DNA molecule. (b). Cores of Dane particles obtained at the higher density, which do not extrude DNA molecules: (a) and (b). EM. $\times 15000$. 


\section{RESULTS}

When Dane-particle cores labelled with $\left[{ }^{3} \mathrm{H}\right] \mathrm{TTP}$ were centrifuged in a metrizamide density gradient, two peaks of $\mathrm{HB}_{\mathrm{c}} \mathrm{Ag}$ activity appeared. The fractions corresponding to each peak of $\mathrm{HB}_{\mathrm{c}} \mathrm{Ag}$ activity were pooled separately, and subjected again to ultracentrifugation in a similar gradient. Patterns of $\mathrm{HB}_{\mathrm{c}} \mathrm{Ag}$ and radioactivity for each peak are illustrated in figs. $1 \mathrm{~A}$ and $1 \mathrm{~B}$. It is obvious that the $\mathrm{HB}_{\mathrm{c}} \mathrm{Ag}$ peak at the lower density $\left(1.19-1.23 \mathrm{~g} / \mathrm{cm}^{3}\right)$ is associated with radioactivity. In contrast, radioactivity was not detected in the $\mathrm{HB}_{\mathrm{c}} \mathrm{Ag}$ peak at the higher density $\left(1.23-1.27 \mathrm{~g} / \mathrm{cm}^{3}\right)$, although the titre of $\mathrm{HB}_{\mathrm{c}} \mathrm{Ag}$ was comparable to that of the lower density fractions.

All the radioactive cores obtained at the lower density, when spread in a monolayer and observed in an electron microscope, were seen to extrude a circular, double-stranded DNA molecule (fig. 2a). In contrast, DNA strands were not demonstrable from the cores obtained at the higher density (fig. 2b).

\section{DisCussion}

Although the association of hepatitis $B$ antigen and type- $B$ hepatitis has been established, the virological characterisation of the aetiological agent, $\mathrm{HBV}$, is not yet fully accomplished due, in some part, to the lack of sufficient amounts of HBV available for study. All previous attempts to propagate $\mathrm{HBV}$ in culture have been unfruitful. Therefore, humans and experimental animals carrying HBV still remain the sole source of HBV. Dane particles, the accepted HBV, however, are not always detected in plasma containing $\mathrm{HB}_{\mathrm{s}} \mathrm{Ag}$. Furthermore, it has been reported that Dane particles in the plasma are heterogeneous. Kaplan et al. (1976) found two kinds of core particles with different densities one of which was associated with DNA polymerase while the other was not.

Two things have to be taken into account in the preparation of HBV from plasma. Firstly, plasma containing Dane particles at a high concentration has to be selected; secondly, empty, defective Dane particles must be removed. We have purified Dane particles from plasma containing $\mathrm{HB}_{\mathrm{s}} \mathrm{Ag}$ and $\mathrm{HB}_{\mathrm{e}} \mathrm{Ag}$. $\mathrm{HB}_{\mathrm{e}} \mathrm{Ag}$ is regarded as an indicator of the presence of Dane particles in a high concentration because it is closely associated with $\mathrm{HB}_{\mathrm{c}} \mathrm{Ag}$ and $\mathrm{HBV}$-specific DNA polymerase (Nordenfeld and Kjellen, 1975; Imai et al., 1976; Takahashi, K. et al, 1976). In the present report, equilibrium ultracentrifugation in metrizamide density gradient has been successfully applied to the separation of the cores of Dane particles containing a DNA strand, taking advantage of the fact that the density of DNA decreases markedly in metrizamide solution because it becomes hydrated (Birnie et al., 1973). The availability of Dane particles is limited only by shortage of plasma containing Dane particles. By the use of enough plasma containing $\mathrm{HB}_{\mathrm{s}} \mathrm{Ag}$ and $\mathrm{HB}_{\mathrm{e}} \mathrm{Ag}$, a sufficient quantity of hepatitis $\mathrm{B}$ virus nucleocapsid can be obtained to allow the analysis of HBV-specific DNA and related studies.

\section{SUMMARY}

Dane-particle cores labelled with $\left[{ }^{3} \mathrm{H}\right] \mathrm{TTP}$ were subjected to ultracentrifugation in a metrizamide density gradient. Two populations of core particles with different densities were obtained, and radioactivity was found only in the cores that sedimented at the lower density $(1 \cdot 19-1 \cdot 23$ $\mathrm{g} / \mathrm{cm}^{3}$ ). All the cores in this group, when spread in a monolayer, were found to expel a closed circular double-stranded DNA molecule. In contrast, the core particles that sedimented at the higher density $\left(1.23-1.27 \mathrm{~g} / \mathrm{cm}^{3}\right)$ were not associated with radioactivity, nor was any DNA strand extruded from them. These results show that metrizamide density gradients allow the separation of complete hepatitis B virions for the study of viral DNA.

This work was supported in part by grants from the Japanese Ministry of Health and Welfare and the Tokyo Metropolitan Government. We thank the Japan Red Cross Association for blood units containing hepatitis $B$ antigens. 


\section{REFERENCES}

Almeida, J. D., Rubenstein, D. And Stott, E. J. 1971. New antigen-antibody system in Australia-antigen-positive hepatitis. Lancet, 2, 1225.

Birnie, G. D., Rickwood, D. AND Hell, A. 1973. Buoyant densities and hydration of nucleic acids, proteins and nucleoprotein complexes in metrizamide. Biochim. biophys. Acta, 331, 283.

Dane, D. S., Cameron, C. H. AND Briggs, M. 1970. Virus-like particles in serum of patients with Australia-antigen-associated hepatitis. Lancet, 1, 695.

Imai, M., Tachibana, F. C., Moritsugu, Y., Miyakawa, Y. and Mayumi, M. 1976. Hepatitis $B$ antigen-associated deoxyribonucleic acid polymerase activity and e antigen/anti-e system. Infect. Immun., 14, 631 .

Kaplan, P. M., Greenman, R. L., Gerin, J. L., Purcell, R. H. and Robinson, W. S. 1973. DNA polymerase associated with human hepatitis B antigen. J. Virol., 12, 995.

Kaplan, P. M., Ford, E. C., Purcell, R. H. and Gerin, J. L. 1976. Demonstration of subpopulations of Dane particles. J. Virol., 17, 885 .

KLEINSCHMIDT, A. K. 1968. Monolayer techniques in electron microscopy of nucleic acid molecules. In Methods of enzymology, edited by S. P. Colowick and N. O. Kaplan. Academic Press: New York, vol. XIIb, p. 361.

Magnius L. O. AND Espmark, J. A. 1972. New specificities in Australia antigen positive sera distinct from Le Bouvier determinants. J. Immunol., 109, 1017.

Moritsugu, Y., Gold, J. W. M., Wagner, J., Dodd, R. Y. and Purcell R. H. 1975. Hepatitis B core antigen. Detection of antibody by radioimmuno-precipitation. $J$. Immunol., 114, 1792.

NoRdENFELD, E. AND KJELLEN, L. 1975. Dane particles, DNA polymerase, and e-antigen in two different categories of hepatitis B antigen carriers. Intervirology, 5, 225.

Takahashi, K., Imai, M., Tsuda, F., Takahashi, T., Miyakawa, Y. and Mayumi, M. 1976. Association of Dane particles with e antigen in the serum of asymptomatic carriers of hepatitis B surface antigen. J. Immunol., 117, 102.

Takahashi, T., Nakagawa, S., Hashimoto, T., Takahashi, K., Imai, M., Miyakawa, Y. and MAYUMI, M. 1976. Large-scale isolation of Dane particles from plasma containing hepatitis B antigen and demonstration of a circular double-stranded DNA molecule extruding directly from their cores. J. Immunol., 117, 1392.

Tsuda, F., Takahashi, T., Takahashi, K., Miyakawa, Y. and Mayumi, M. 1975. Determination of antibody to hepatitis $B$ core antigen by means of immune adherence hemagglutination. J. Immunol., 115, 834. 